\title{
Are the Early Leavers the Lucky Ones?'
}

\section{Pekka Virtanen}

Senior Research Fellow, Faculty of Social Sciences, University of Tampere, Finland

\section{Arja Jolkkonen}

Senior Researcher, Karelian Institute, University of Eastern Finland, Finland

\section{Pertti Koistinen ${ }^{2}$}

Professor Emeritus, Faculty of Social Sciences, University of Tampere, Finland

\section{Arja Kurvinen}

Senior Researcher, Karelian Institute, University of Eastern Finland, Finland

\section{Liudmila Lipiäinen}

Researcher, Faculty of Social Sciences, University of Tampere, Finland

\section{Tapio Nummi}

University Lecturer, Faculty of Information Technology and Communication Sciences, University of Tampere, Finland

\begin{abstract}
According to previous studies, major workforce downsizings are commonly preceded by increased employee turnover due to 'early leavers'. There is a common belief that early leavers are winners in terms of re-employment. This seven-year follow-up study based on register data from Finland questions if this is a valid finding in the Nordic context. We set the hypothesis that early leavers are not undisputed winners compared with those who leave during the actual downsizing. Trajectory and sequence analyses were used to test the hypothesis. Six employment trajectories were identified, ranging from permanently strong to permanently weak labor market attachment. Supporting the hypothesis, the early leavers assumed more commonly the weak and less commonly the strong employment trajectory. However, within the weak employment group, the early leavers and ultimately displaced workers were equal in terms of unemployment and retiring, as well as within the strong employment group in terms of income level.
\end{abstract}

\section{KEYWORDS}

Early leavers / employment trajectories / job mobility / plant closing / segmentation / sequence analysis / trajectory analysis / workforce downsizing

\footnotetext{
${ }^{1}$ You can find this text and its DOI at https://tidsskrift.dk/njwls/index.

${ }^{2}$ Corresponding author: pertti.koistinen@tuni.fi.
} 


\section{Introduction}

ajor workforce downsizings, such as complete plant closures, may be common and often shocking events, but they are seldom unexpected. Rather, they are forecasted by a less dramatic increase in employee turnover, which in the case of downsizing may continue even in the aftermath of the major event (Eliason \& Storrie 2006, p. 835-836; Lengerman \& Wilhuber 2002; Pfann \& Hamermesh 2008; Schwerdt 2011). There is a tradition of research stretching over 30 years that utilizes a distinction between employees who leave a workplace prior to a major downsizing ('early leavers') and those who are displaced during the major downsizing ('ultimately displaced workers') with the aim of increasing the visibility of the functioning of the labor market and the variation of unemployment risks (Addison \& Portugal 1987; Folbre et al. 1984).

Previous studies clearly indicate that a financially distressed firm may lay off individual or small groups of low-productive workers (Henningsen \& Hægeland 2008; Lengerman \& Wilhuber 2002) and reduce the renewal of temporary contacts and the use of temporary agency staffing. Employees also react when such events and the associated information about financial problems signal a threat to the continuity of their jobs. Those with the best re-employment resources - such as strong networks, including relationships with previous employers, and knowledge and skills that are in demand in the labor market - may quit in advance (Schwerdt 2011). Another group that tends to move into the external labor market includes those who think that they would not survive the stiffening competition for posts at their current employer (Huttunen et al. 2011; von Greiff 2009). There are also employees who can utilize - more or less voluntarily opportunities to enter into institutional arrangements, such as retirement, re-education, or rehabilitation (Bratsberg et al. 2013).

Besides, an exit due to ordinary turnover, the particular exit that precedes the downsizing can be characterized as being based on anticipation, where the main actor is either the employer or the employee, or as Lengermann and Vilhuber $(2002$, p. 17) put it succinctly: 'Management can hire and fire, workers can quit'. Therefore, early leavers consist of several subgroups, and they are evidently more heterogeneous than the employees who lose their jobs during a major downsizing (Addison \& Portugal 1987; Henningsen \& Hægeland 2008; Jolkkonen \& Kurvinen 2009; Schwerdt 2011).

The existing research clarifies the roles of the employer and employees and regulative institutions in the process of restructuring; it also helps in identifying what policies work and for whom, when targeting workers at risk of job losses. Despite the undisputed progress in the research, there are still gaps in knowledge and a need for generalizability of the findings, especially in the institutional context of the Nordic welfare state.

Among other things, earlier studies suggest that early leavers form a more fortunate group regarding post-risk employment and income. Therefore, early leavers are often seen as an example of career mobility in internal and external labor markets (Valenduc 2018). It should be emphasized that selection and re-employment still contain a number of unobserved factors that have not been considered in earlier studies, either due to the limitations or definition of the data or for methodological reasons. This article concerns early leavers, irrespective of the logic or the principal actor of the exit (see Pfann \& Hamermesh 2008). We ask, whether early leavers are luckier than ultimately displaced workers in terms of employment prospects and income. This seven-year follow-up study based on register data from Finland questions if the common belief that early leavers are

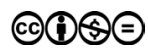


winners in terms of re-employment is a valid finding in the Nordic context. We set the hypothesis that early leavers are not undisputed winners compared with those who leave during the actual downsizing and tested the hypothesis with trajectory and sequence analyses.

\section{Background}

\section{Theoretical context}

The employees of interest are termed here 'early leavers', which refers to information and job mobility as the major forms of the labor market adjustment. According to Cahuc et al. (2014), Stigler $(1961,1962)$ was the first to point out that when equipped with more or less perfect information, the job seeker explores the labor market to find the job that offers the highest reward for the services that he or she can supply. Modern job search theory arose in the 1970s with formulations by McCall (1970) and Mortensen (1970; see Cahuc et al. 2014, p. 254). While holding on to imperfect information as the prominent concept, the theory was developed by introducing the unemployed as a separate category. In completing the employed versus nonparticipant dichotomy with the unemployed, the theory sheds supplementary light on the decision to participate in the labor market, which no longer takes the form of a choice between work and nonparticipation; rather, the choice lies in knowing whether it is worthwhile to look for a job.

In the context of an impending major downsizing and associated early leaving, the importance of the information for job mobility and stability is evident. Employees are forced to assess the risk of being laid off from their current job against the risk of not being able to gain and hold on to another job. As a result, risk-averse employees who, under 'normal' circumstances, tend to stay (see van Huizen \& Alessie 2016) may prefer to leave, whereas risk-neutral employees will stay.

Furthermore, the research on job quitting behavior tends to pay more attention to the competitiveness in the labor market than to the employment prospects within the current organization. Using US data, Holmlund and Lang (1985) studied the quitting behavior of workers under incomplete information. They concluded that when holding wage rates constant, workers with long tenure are less likely to resign, whereas workers who could be considered to be risk-neutral are willing to accept a wage offer that falls below their current 'full' wage. More recent studies indicate that poor job search performance may lead individuals to adjust their expectations downwards and search less (Bonin et al. 2007), and that the displaced workers with high firm-specific wage components in their previous jobs have higher reservation wages and, as a result, longer durations of unemployment (Böheim et al. 2011). Both studies suggest a potential role for information and feedback, but Beam (2016, p. 2) argues that the impacts of information provision in actual job searches have not been quantified.

Along with the availability of longitudinal data, the theory of incomplete information has been developed, and associated hypotheses have been tested empirically. A Dutch study that includes detailed information on workers' labor market behavior (van Huizen et al. 2016) examined the relationship between experimentally measured risk preferences and actual job mobility. The findings show that risk averse workers are less likely to move to other jobs. In line with the theoretical predictions, the negative 
relationship between the risk aversion and mobility is stronger if the worker holds a permanent contract and is in a good job match, and when the demand for labor decreases. This evidence indicates that the effects are driven by the job acceptance decision rather than the search decision. In addition, workers who have experienced unemployment or previous displacement are more aware and sensitive to information about the impending downsizing. In order to avoid such experiences, they are ready to accept the available offers, even when the pending job would require a shift into a lower status occupation, reduced income, and inferior contractual conditions (Burda \& Mertens 2001; Knabe \& Rätzel 2009; Lim et al. 2016).

In this article, the early leavers will be contrasted with the ultimately displaced workers. The latter group refers to the employees who no longer have a choice whether to leave or not due to the actualization of the anticipated major downsizing. In terms of information theory, they had considered, despite the risks, that staying in their job will be more beneficial than leaving. Furthermore, because the employer had elected to keep them until the major downsizing, they evidently belonged to the core workforce of the company.

In addition to the context of the economic situation of the company and the local labor market, losing a job happens in the context of the business cycle and national societal institutions. This means that the labor market partners, employment protection legislation, welfare services, and, in particular, insurance benefits affect the way in which the employers and employees adapt to various risks and employment positions. In terms of theory, institutions, and regulations, the early leavers and the ultimately displaced workers are treated differently. In the case of early leavers, the institutional opportunities and constraints are assumed to affect the behavior of the employees and the employers to a lesser extent than in the case of the ultimately displaced workers.

The differentiation of labor market outcomes of major workforce downsizings and plant closures can also be inspected in the frame of the insider-outsider theory (Lindbeck \& Snower 1988, 2001). The differences in the positions and opportunities of the different groups of employees affect their labor market behavior. In order to explain the differences in the positions and opportunities of the different groups of employees, Lindbeck and Snower made a distinction between 'insiders' and 'outsiders'. The insiders often enjoy more favorable employment opportunities than the outsiders. This theoretical distinction can also be applied to understand the process that leads to the segmentation of early leavers and ultimate displaced workers. Emmenegger et al. (2012) used this distinction between insiders and outsiders to interpret the dualization and polarization of the labor market. According to them, Nordic countries witness lower levels of insideroutsider divides than the continental European welfare states and seem to be a result of a more universal and egalitarian design of welfare policies and strong political interaction of outsiders. However, the institutional dualization through the pension system is quite strong also in Finland, Norway, and Sweden.

\section{Studies on early leavers}

Using data from the US Displaced Workers Survey, Addison and Portugal (1987) analyzed the effect of early announcements on the duration of the unemployment spells of those who received benefits from an unemployment security scheme, versus those who 
did not receive benefits. They replicated the finding of Folbre et al. (1984), who found that the duration of unemployment was shorter among the notified workers, particularly among those who did not draw unemployment insurance benefits. From the viewpoint of this article, the most interesting finding in the study of Addison and Portugal (1987) is that those leaving the plant prior to the shutdown experienced significantly less unemployment independent of the announcement and the benefits. In accordance with this result, a more recent study from the US (Bowlus \& Vilhuber 2001) showed that workers leaving a 'distressed' firm have higher re-employment wages than workers who stay with the firm until displacement. Bowlus and Vilhuber also point out that early leavers' re-employment wages may be endogenously relatively low, and, therefore, it is more appropriate to compare them with the displaced than with those who continue in the company. In other words, even if re-employed equally, the workers displaced during the downsizing suffer from worse wage penalties, compared with the early leavers.

An Austrian study utilizing the administrative register data of private sector employees in the 1980s (Schwerdt 2011) lends support to the hypothesis that early leavers survive with relatively low job-loss costs. This was indicated both by a higher probability of re-employment and by a lower loss of re-employment wages. The result was related to the finding that their pre-closure earnings were higher than the earnings of a comparison group and those who left just prior to the plant closing. Based on an analysis of the pre-closure processes, Schwerdt concludes that, when anticipating the closure, the logic of 'leaving the sinking ship' applies, in particular, to relatively highly skilled and young employees with better labor market opportunities, whereas lower skilled and less productive employees tend to become treated by the employer as 'ballast thrown overboard'. The conclusion is consistent with a study from the US (Lengermann \& Vilhuber 2002, p. 23), which found that in the periods prior to displacement, 'churning rates increase for all skill groups, but the retention rates drop for high-skilled workers'.

Given a few studies on the re-employment of early leavers, there are reasons to ask if the results suggesting that they are in a relatively strong position in terms of reemployment (Bowlus and Vilhuber 2001; Folbre et al. 1984; Schwerdt 2011) can be generalized internationally and over time. A Finnish study by Korkeamäki and Kyyrä (2014) indicates that the results might not hold true in the Nordic context. Regarding the findings of Korkeamäki and Kyyrä, it is important to consider that the study was designed mainly to analyze if displacement during an economic depression is followed by a greater wage loss than displacement during an economic recovery when compared with the wage development of the employees who were not displaced. Interestingly, for this article, the study also includes a group of 'early leavers' who left the plant during the year preceding the downsizing or closure. The earnings of this group seemed to remain lower than that of the control group and the displaced. However, the study was not originally designed for such comparisons. The authors conclude, 'one should recognize that the early leavers separated from different plants than the members of the displacement groups. As a consequence, the comparison of the groups is not straightforward and the findings for the early leavers should be treated with caution' (Korkeamäki \& Kyyrä 2014, p. 585).

Thus, in studies regarding the costs of the job losses of the ultimately displaced workers only, the employee group to be displaced is more or less particular; that is, the sample may be selected due to the 'displaced worker bias' (see Pfann \& Hamermesh 2008). For example, Finnish studies on unemployment and earnings penalties after plant closures (Verho 2008) and on the wage and earning losses of the displaced (Appelquist 2007) pay 
virtually no attention to such a bias. A Danish study (Frederiksen \& Westgaard-Nielsen 2007) shows that employees displaced from downsizing or closing establishments are more likely to become re-employed and less likely to become unemployed, compared with those leaving a stable or an expanding company, but this study also neglects the potential importance of those leaving early in anticipation of a downsizing or closure. A Swedish study (von Greiff 2009) indicates the high probability of entering self-employment after a plant closure, especially among those who are in a worse position in the labor market, but it remains unclear whether this finding holds true in the case of early leaving. In addition to being of interest as such, knowledge on early leaving is important for the interpretation of findings from studies that focus on major downsizings.

\section{Hypotheses}

Leaning on the theory of imperfect information, we suppose that advance information affects the behavior of both employees and employers, and that there are asymmetries between the workers and the management in terms of access to relevant information. Given the quality and quantity of the information, actors are supposed to act rationally with respect to the opportunities offered by market forces, the labor market, and societal institutions. Among the workers, there are those who decide to 'leave the sinking ship' and those who decide to stay. Moreover, there are employees who would like to stay but are forced to be early leavers, for example, since their work contracts are temporary, or they are offered pension arrangements.

As a result, compared with employees who leave during major downsizings, early leavers obviously constitute a heterogeneous group in terms of the capacity for reemployment. The early leavers are supposed to constitute high skilled workers with promising options, temporary workers at the beginning of their careers and workers with weak labor market opportunities. Ultimately, displaced workers are supposed to search for new jobs, participate in education or employment measures, or be retired. Nevertheless, both early leavers and ultimately displaced workers are 'mobile'; they have all moved, or are attempting to move, to a new place in the labor market, and, thus, are at risk of marginalization.

Regarding empirical evidence about this risk, the early studies with relatively old data from other countries give rise to hypothesize that early leavers incur relatively low risk, whereas more recent research, in particular from Finland, gives rise to suspect that their risk is relatively high. Also, our main aim is to test the hypothesis that the labor market attachment of the early leavers is weaker than the attachment of the ultimately displaced counterpart workers.

However, we expect to see a dual development among the early leavers as well as among the ultimately displaced workers; in other words, in these both major groups, there are subgroups with strong and with weak labor market attachment. In the spirit of the insider-outsider dualization, we focus further analyses on the extreme insiders and the extreme outsiders, who survive continuously employed and those with the consistently low level of employment. Regarding the former subgroup, our aim is to reveal potential baseline status related income difference, and regarding the latter subgroup the aim is to disentangle corresponding differences with respect to the institutions of the welfare state, such as unemployment benefit and pension schemes. 


\section{Methods}

The design of this seven-year follow-up is based on the idea of pooling the early leavers and the ultimately displaced workers, of defining various patterns of the labor market attachment of this total sample, and of analyzing potential differences in the attachment with respect to the status at the baseline of the follow-up. Number of the months worked annually is used as the measure of the labor market attachment.

\section{Data and sample}

The Finnish Longitudinal Employer-Employee Data (FLEED, Statistics Finland) consists of a random sample of every third individual aged 15-70 years living in Finland since 1988. Statistics Finland collects information on their employment history, income, and individual characteristics from several administrative registers. There is also a variable indicating their main activity during each year and, for those who are employed, the code of the workplace. Through this code, it is possible to identify from the sample the employees of a given plant and to monitor the size of its staff at the end of each calendar year.

The sample includes employees of plants that employed at least 10 workers at the end of 2004 and had reduced the workforce by at least $30 \%$ by the end of 2005 , including closed plants. The definition is similar to that used by Lengermann and Vilhuber (2002, p. 8) and Martikainen et al. (2007). The data covers both private and publicsector employers. If there had also been a downsizing of over $30 \%$ in 2004 , the workplace was excluded from the sample.

All employees who were working in these plants at the end of 2003, but were no longer employed in the same plant at the end of 2004 - that is, had left during the year that preceded the major downsizing - were included in the study sample and labeled early leavers. A random sample of equal size, labeled ultimately displaced workers, was drawn from those who were working in these plants at the end of 2004 but were no longer employed in the same plant at the end of 2005. Workers who were over 60 years of age in 2004-2005 were excluded in order to ensure that the follow-up period did not extend beyond the age of obligatory retirement ( 68 years).

\section{Variables}

The 'leaver status' variable classified the sample into early leavers and ultimately displaced workers. Three variables indicating the individuals' labor market attachment during the baseline year (2004 for the early leavers and 2005 for the ultimately displaced workers) and the following seven-year period were extracted from the FLEED database: (1) employment measured as the number of months annually; (2) the main activity at the end of each year classified into employed, unemployed, unemployment pensioner, retired (including age- and disability-based retirement), student, and other (outside the labor force for other reasons); and (3) yearly income (wage/salary and business). As background variables, the data included gender, age, education (classified as primary level, secondary level, lower tertiary level, or higher tertiary level), occurrence of unemployment (over one 
month) during the year preceding the leaving year, and the length of the expired contract (employed in the downsizing plant for $0-3$ years or over 3 years).

\section{Trajectory analysis and sequence analysis}

Analysis of the data was first done with a trajectory analysis of the whole sample with annual employment months as the response variable. Trajectory analysis, also called latent class growth analysis (Jung \& Wickrama 2008; Muthén 2001, 2004) or groupbased modelling of development (Nagin 1999, 2005), provides a method to analyze repeated measurements of the studied individuals. It allows for heterogeneity in the population and identifies distinctive groups of individuals with the same type of development pattern. The analysis searches for an appropriate number of trajectory groups and provides estimates of the corresponding statistical models. On this basis, the posterior probability of each individual belonging to each trajectory group can be calculated, and based on the probabilities, an individual can be assigned to the most probable group. Trajectory analysis was used to define groups within the sample that assumed differential levels and developments of employment during the seven years, starting from the year in which they left the plant. The choice of the best solution - that is, the optimal number of trajectory groups - was based on Bayesian information criteria (BIC). In addition, the trajectory groups were required to fulfil the commonsense criterion - that is, every group was required to allow for a real-life interpretation.

After obtaining the trajectory groups, hypothesis was tested. Multinomial logistic regression analysis was applied to compare the early leavers and the ultimately displaced workers with respect to being located in the groups, controlling for gender, age, education, prior unemployment, and the length of the prior employment contract.

Next, the focus was turned to the trajectory group with the weakest labor market attachment. The exit from employment of this group was studied with sequence analysis according to the annual main activities. Sequence analysis is a method for clustering individuals into groups with similar transition histories (Abbott 1995; Aisenbrey \& Fasang 2010; Brzinsky-Fay et al. 2006; Gauthier et al. 2010). The analysis was continued until the information was considered to be saturated - that is, further clustering led to several very small groups. After deciding on the set of sequence groups, the differences between the early leavers, and ultimately, displaced workers in the group memberships were explored.

Finally, the difference in the development of incomes between the continuously employed early leavers and ultimately displaced workers was explored by plotting the leavers' average yearly incomes during seven years after leaving the plant.

\section{Results}

\section{Trajectory analysis and descriptive statistics}

As a full 12-month employment was quite common even in the first follow-up year, from this was subtracted the number of annual employment months in order to obtain a response variable ('non-employment') that follows the Poisson distribution and is, thus, 
suitable for trajectory analysis. It was also assumed that a second-degree polynomial curve fitted the data better than a simple linear curve. Trajectory solutions were tested for up to eight groups. The BIC values decreased from 682,676.1 for one group to 276,887.9 for six groups and the adding of further groups did not decrease the BIC values.

Figure I Seven-year employment trajectories of the employees after leaving the workplace.

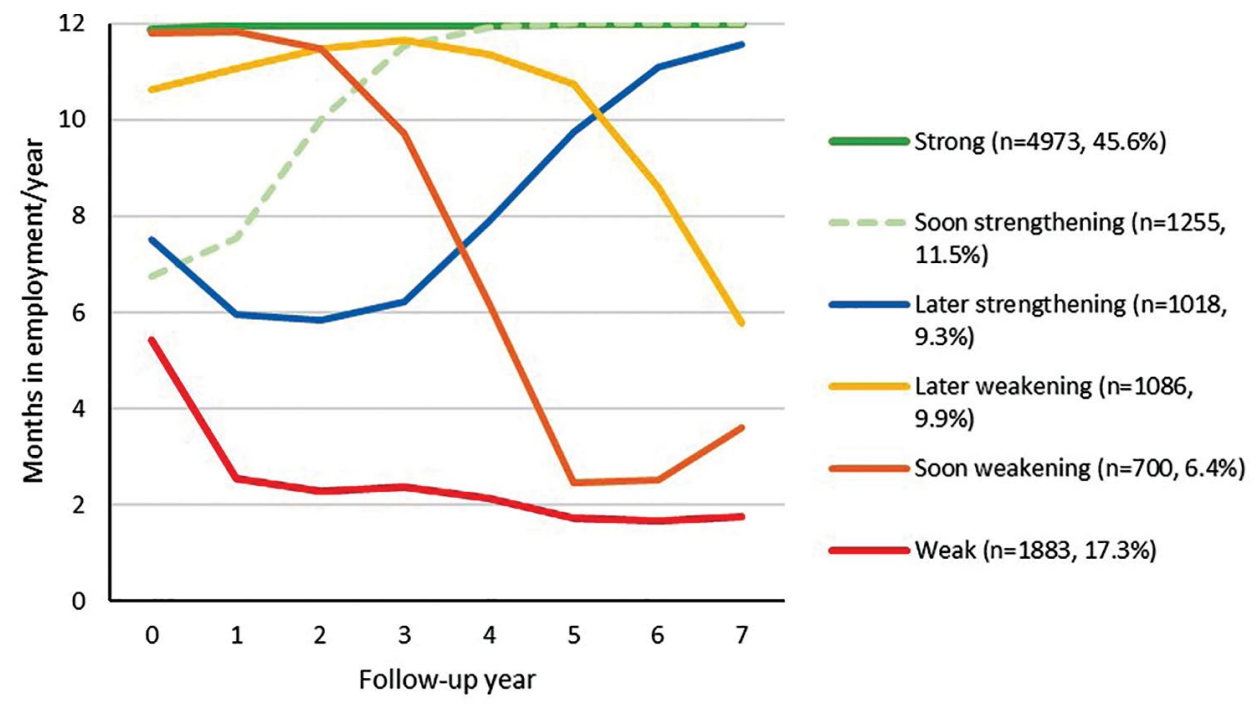

Figure 1 describes the trajectory groups by means of months in employment annually. Almost half of the sample were employed throughout seven follow-up years, whereas a considerably sized group assumed a very low-level employment trajectory. The rest were divided rather evenly into those attaining strong employment after being moderately employed for about three years or about six years, and to those whose employment began to decline soon or later during the follow-up period. These six trajectory groups were labeled, respectively, 'strong', 'weak', 'soon strengthening', 'later strengthening', 'soon weakening', and 'later weakening'.

Descriptive statistics by trajectory group (Table 1 ) show that the early leavers had experienced unemployment more often, had a long employment spell less often, and were slightly younger in comparison with the ultimately displaced workers, while the differences in gender and education were less regular. In both groups, those assuming the immediately weakening or soon weakening trajectory tended to be older and less educated, and to have experienced unemployment.

\section{Trajectories by leaver status}

The trajectory of strong employment was more common (53\% vs. 39\%) and the trajectory of weak employment less common (13\% vs. $22 \%)$ among the ultimately displaced workers than among the early leavers (Table 2). On the other hand, among the early leavers, the proportions of those with soon strengthening or later strengthening employment 


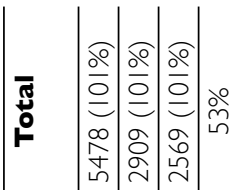

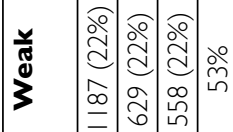

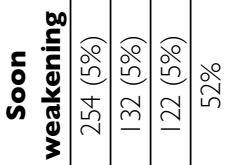

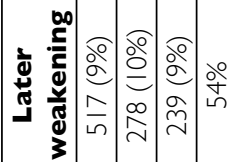

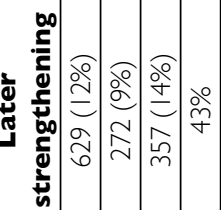

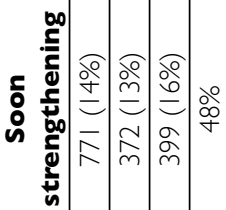

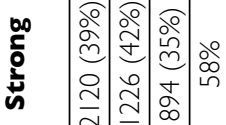

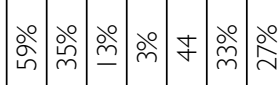

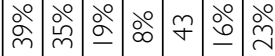

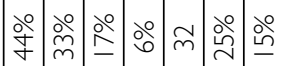

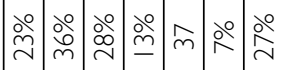

字

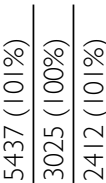

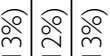

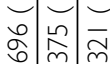

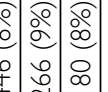

ภำ

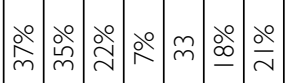

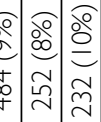

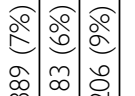

\section{ㅇำ} மூ ஸุ่
๖ำ

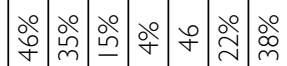

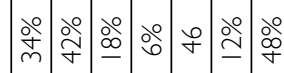

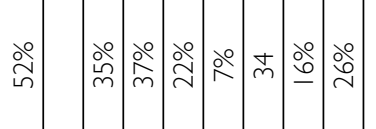

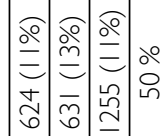

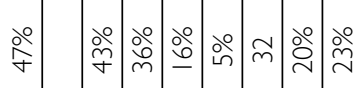

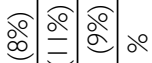
岗

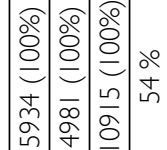

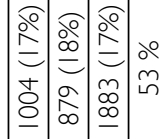

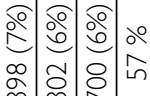

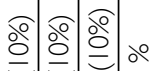

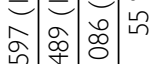

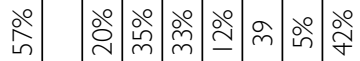

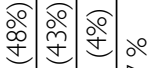
只

$\frac{\mathscr{U}}{\underline{U}}$
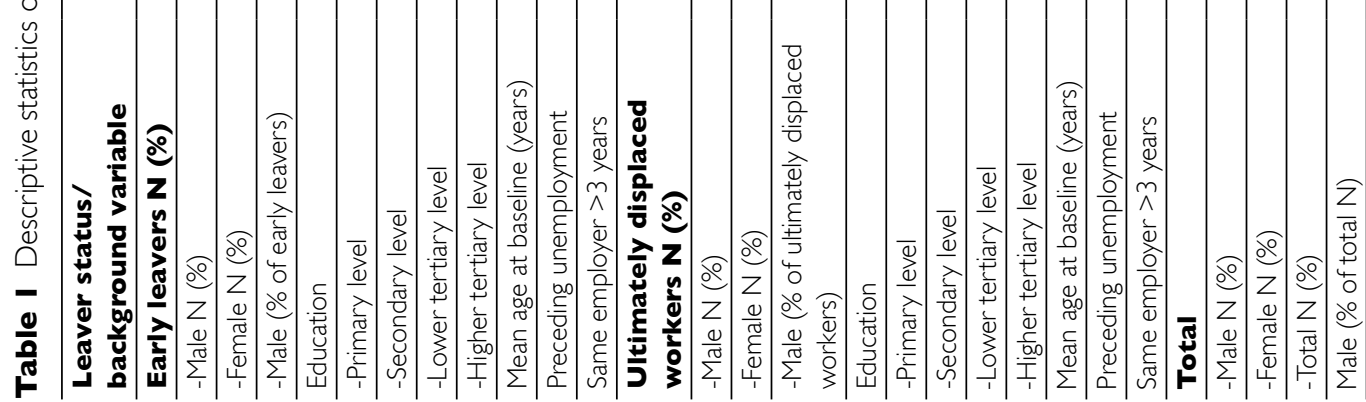
Table 2 Early leavers and ultimately displaced workers according to employment trajectory (percentages on two upper lines)

\begin{tabular}{|c|c|c|c|c|c|c|}
\hline Leaver status & Strong & $\begin{array}{c}\text { Soon } \\
\text { strengthening } \\
\end{array}$ & $\begin{array}{c}\text { Later } \\
\text { strengthening } \\
\end{array}$ & $\begin{array}{c}\text { Later } \\
\text { weakening }\end{array}$ & $\begin{array}{c}\text { Soon } \\
\text { weakening }\end{array}$ & Weak \\
\hline Early leavers & $39 \%$ & $14 \%$ & $11 \%$ & $9 \%$ & $5 \%$ & $22 \%$ \\
\hline Ultimately displaced & $53 \%$ & $9 \%$ & $7 \%$ & $11 \%$ & $8 \%$ & $13 \%$ \\
\hline Early leavers & Ref & Ref & Ref & Ref & Ref & Ref \\
\hline - RRR (95\% Cl) (I) & Ref & $\begin{array}{c}0.47 \\
(0.4-0.5) \\
\end{array}$ & $\begin{array}{c}0.46 \\
(0.4-0.5) \\
\end{array}$ & $\begin{array}{c}0.81 \\
(0.7-0.9) \\
\end{array}$ & $\begin{array}{c}1.28 \\
(1.1-1.5) \\
\end{array}$ & $\begin{array}{c}0.43 \\
(0.4-0.5) \\
\end{array}$ \\
\hline - RRR (95\% Cl) (2) & Ref & $\begin{array}{c}0.53 \\
(0.5-0.6)\end{array}$ & $\begin{array}{c}0.53 \\
(0.5-0.6)\end{array}$ & $\begin{array}{c}0.80 \\
(0.7-0.9)\end{array}$ & $\begin{array}{c}1.14 \\
(0.96-1.4)\end{array}$ & $\begin{array}{c}0.39 \\
(0.4-0.4)\end{array}$ \\
\hline - RRR (95\% Cl) (3) & Ref & $\begin{array}{c}0.55 \\
(0.5-0.6) \\
\end{array}$ & $\begin{array}{c}0.55 \\
(0.5-0.6) \\
\end{array}$ & $\begin{array}{c}0.82 \\
(0.7-0.9) \\
\end{array}$ & $\begin{array}{c}1.18 \\
(0.997-1.4) \\
\end{array}$ & $\begin{array}{c}0.43 \\
(0.4-0.5) \\
\end{array}$ \\
\hline - RRR (95\% Cl) (4) & Ref & $\begin{array}{c}0.55 \\
(0.5-0.6)\end{array}$ & $\begin{array}{c}0.57 \\
(0.5-0.7)\end{array}$ & $\begin{array}{c}0.84 \\
(0.7-0.97)\end{array}$ & $\begin{array}{c}1.2 \\
(1.01-1.4)\end{array}$ & $\begin{array}{c}0.43 \\
(0.4-0.5)\end{array}$ \\
\hline
\end{tabular}

The relative risk ratios (RRR) express risk of being ultimately displaced worker within soon strengthening, later strengthening, later weakening, soon weakening, and weak trajectory groups, as compared to the proportion of ultimately displaced workers in the strong trajectory group. Bold font indicates a statistically significant difference in risk.

I: unadjusted; 2: gender, age and education; 3:2 + occurrence of unemployment; $4: 3$ + length of employment

were higher, and the proportions of soon weakening and later weakening employment were lower than among the ultimately displaced workers. Men more often ended up to the trajectory of strong employment than women among the early leavers. Whereas among ultimately displaced workers, there were only minor gender differences. According to the multinomial logistic regression analyses, the soon strengthening, the later strengthening, and, in particular, the weak trajectory were significantly less common among the ultimately displaced workers, whereas the soon weakening trajectory tended to be more common. This pattern of associations remained unchanged after controlling for the set of important background variables.

The available register data does not allow for a more detailed analysis of the early leavers, but referring to the information hypothesis, the above result indicates that, in most cases, the main information holder and an anticipating actor was the employer, who selected the employees that were displaced in anticipatory minor downsizings or restructuring-related turnover. Overall, this process can be characterized as a reduction in the 'buffer workforce' or in employees with various temporary contracts. The share of early leavers who were displaced because the employer assessed them to be unproductive was evidently substantial if we consider that the properties that made them unproductive were also reflected in their difficulties in attaining re-employment during the follow-up.

\section{Ways out of employment in the 'weak employment' group by leaver status}

A set of six sequence clusters (Figure 2) was considered to most optimally describe the main activities during the follow-up among those assuming the trajectory of weak employment. 
Figure 2 Sequence analysis of the seven-year labor market status of the employee group with permanently weak employment after leaving the workplace.

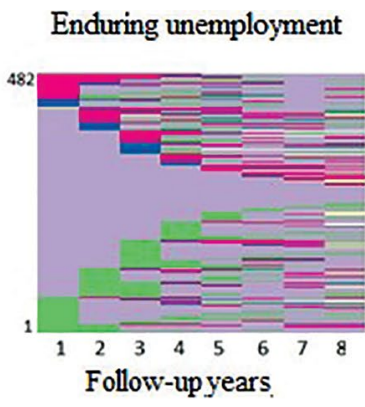

Unemployment pension

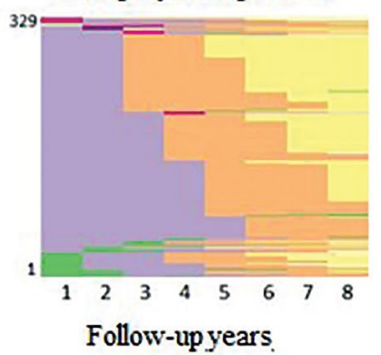

Unstable employment
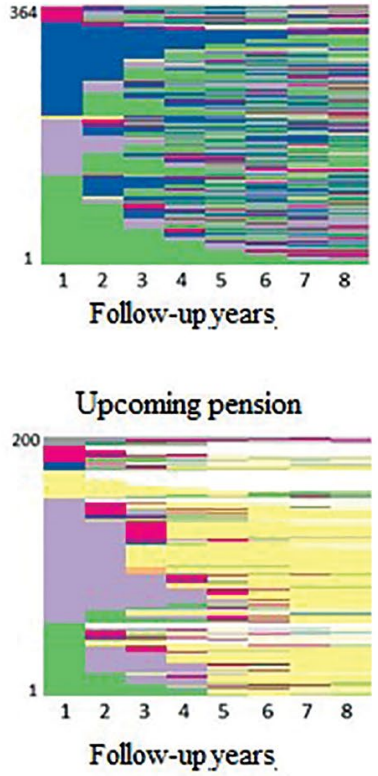

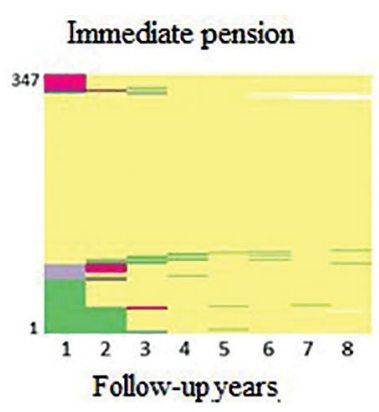

Miscellaneous exits

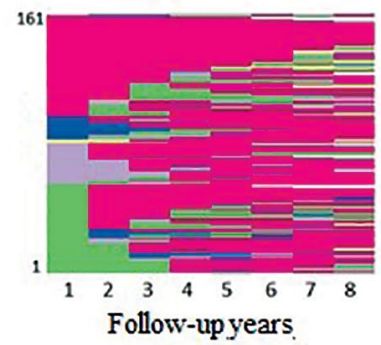

$\square$ Employed
$\square$ Unemployed

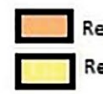

Receiving unemployment pension Retired

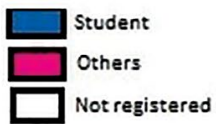

The biggest cluster ( $\mathrm{n}=482,26 \%$ ) was named 'enduring unemployment'; the clusters of 'unstable employment' ( $\mathrm{n}=364,19 \%)$, 'immediate pension' ( $\mathrm{n}=347,18 \%)$, and 'unemployment pension' ( $\mathrm{n}=329,17 \%$ ) were of about equal size, while 'upcoming pension' $(\mathrm{n}=200,11 \%)$ and 'miscellaneous exits' $(\mathrm{n}=161,9 \%)$ were less common.

Table 3 presents the clusters according to leaver status. The unemployment pension was more common and immediate pension less common among ultimately displaced workers. Moreover, enduring unemployment and unstable employment were somewhat more common among the early leavers. The difference in the unemployment pension cluster also stood out in terms of statistical significance $(p=0.030$, Bonferroni corrected Chi-squared test).

When interpreting this result, we must keep in mind that early leavers were over-represented among the employees assuming the trajectory of permanently weak employment. Thus, an equal distribution of the early leavers and the ultimately displaced workers to the sequence groups at the level of this single trajectory group does not mean equality at the level of the whole sample. Rather, the result reveals that the more common permanent marginalization among the early leavers is largely 
Table 3 The trajectory group of immediately weakening employment according to leaver status and the type of main activity status sequence during the seven-year follow-up

\begin{tabular}{lcccc}
\hline \multirow{2}{*}{ Sequence type } & \multicolumn{4}{c}{ Leaver status } \\
\cline { 2 - 5 } & \multicolumn{2}{c}{ Early leavers } & \multicolumn{2}{c}{ Ultimately displaced } \\
\cline { 2 - 5 } & $\mathbf{N}$ & $\%$ & $\mathbf{N}$ & $\%$ \\
\hline Enduring unemployment & 317 & 26,7 & 165 & 23,7 \\
\hline Unstable employment & 240 & 20,2 & 124 & 17,8 \\
\hline Immediate pension & 208 & 17,5 & 139 & 20,0 \\
\hline Unemployment pension & 185 & 15,6 & 144 & 20,7 \\
\hline Upcoming pension & 128 & 10,8 & 72 & 10,3 \\
\hline Miscellaneous exits & 109 & 9,2 & 52 & 7,5 \\
\hline All & 1187 & 100 & 696 & 100 \\
\hline
\end{tabular}

independent of the route of exit. On the other hand, the finding depicts the mutual importance of different institutional pathways. Unemployment insurance and the related pension system were the income sources for almost two-thirds - most of the rest sooner or later received the traditional (i.e., old age or disability) pensions - while one in ten disappeared from the labor market for reasons that could not be elicited from the data. All in all, the result reveals that the particular support programs that are stipulated, agreed on, or adopted in mass downsizing or closings barely have an impact on the types of permanent exit from employment: only unemployment pensions were, somewhat, more common among the ultimately displaced workers, perhaps because in their cases, the opportunities to enter the various pension schemes are sorted out very carefully.

\section{Earnings in the 'strong employment' group by leaver status}

Figure 3 presents the development of earnings in the trajectory group of strong employment separately for the ultimately displaced workers and the early leavers. The curves almost completely overlap during the follow-up years (2005-2011). The distributions of the earnings were also quite similar throughout the years (figures not shown). Moreover, as can be seen from the 'Strong' column in Table 1, the backgrounds of the early leavers and the ultimately displaced were quite similar. In other words, once an employee is re-employed without delay, the time in which the individual left has no decisive impact on future earnings.

In terms of absolute figures, the annual earnings of the strong attachment group rose from 34,500 euro in 2005 to 44,000 euro in 2011, while, in the same period, average earnings in Finland rose from 30,600 euro to 37,300 euro (Statistics Finland, PX-Web Database). Thus, in addition to strong labor market attachment, these leavers were relatively well paid, and their incomes grew quite rapidly $(27.5 \%$ vs. $21.7 \%$ among average wage earners). Still, it must be noted that, among the early leavers, relatively few assumed the trajectory of strong attachment. 
Figure 3 Annual earnings of the strong attachment group.

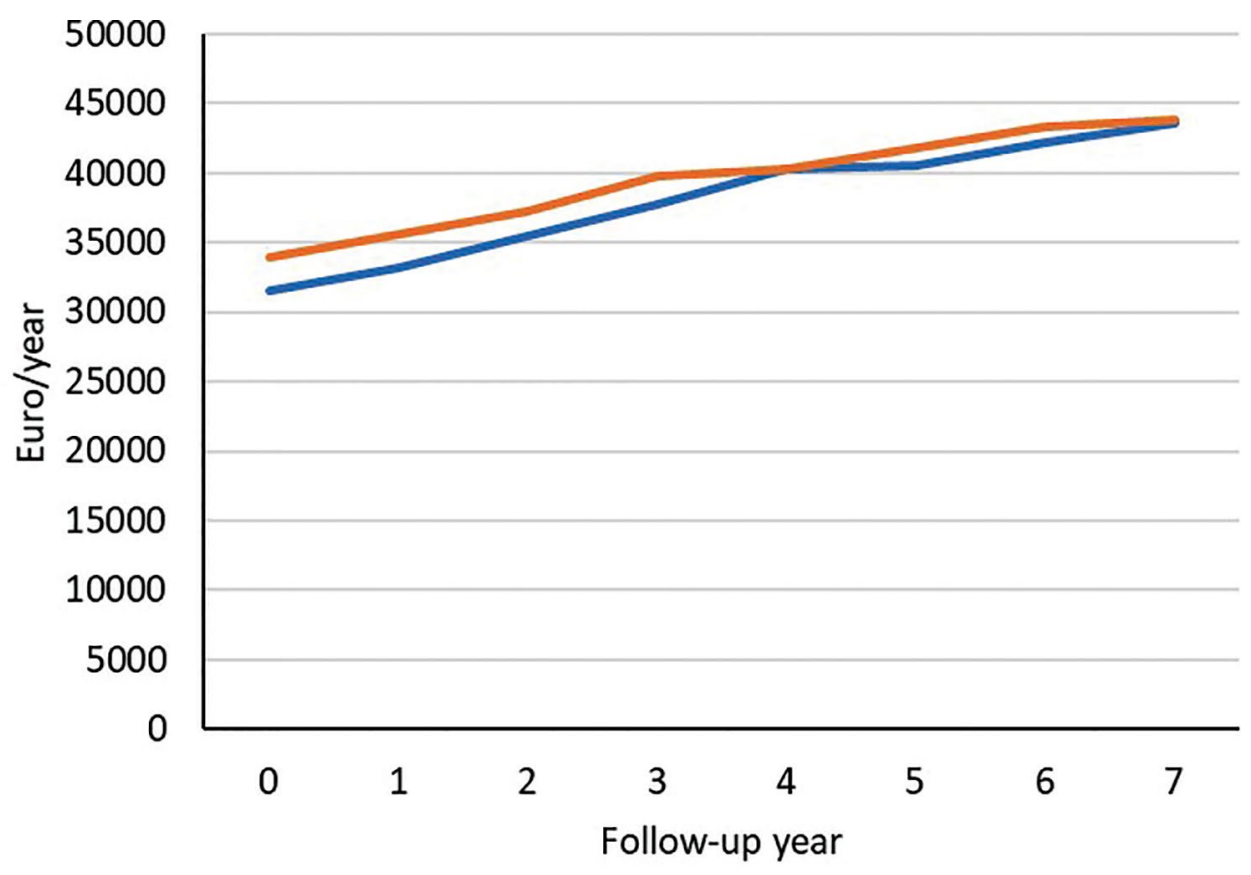

Early leavers UUltimately displaced

\section{Discussion}

\section{Support for the hypothesis: Early leavers are not the lucky ones}

By using the annual working months as a criterion for measuring employment for statistical analyses, this article showed that, compared with employees who lose their job in the context of mass layoffs, employees who leave during the preceding year are not the lucky ones. In contrast, these 'early leavers' had poorer prospects over the next seven years. In line with our expectations, they were distributed into the six trajectories of varying labor market attachment in a more heterogeneous manner than those who lost their jobs during major downsizings, namely 'ultimately displaced workers'. More than half of the ultimately displaced workers continued on the trajectory of strong employment, whereas the corresponding proportion for the early leavers was $39 \%$. A clear difference in favor of ultimately displaced workers (13\% vs. $22 \%)$ was also seen in the prevalence of weak employment. On the other hand, early leavers were more commonly found on the trajectories of soon strengthening and later strengthening employment. The difference in later weakening employment was relatively small.

Overall, our results demonstrated that a large proportion of employees survives major restructurings without interruptions in their employment. The groups with 
strengthening or weakening employment trajectories over the seven-year follow-up raise interesting questions about the processes of entry into and exit from employment. It is evident that public and private measures, such as, re-education, active labor market policy measures, and pension schemes play important roles in buffering and redistributing the social risks of job loss. In this article, we did not continue with the analysis of these groups, but inspected more closely the most extreme trajectory groups, that is, those with a strong labor market attachment and those who dropped immediately into permanently weak employment.

\section{The time to leave is not decisive for social security among the marginalizing workers}

With the aim to compare the early leavers ending up on the trajectory of weak employment ultimately displaced workers assuming a similar trajectory, the sequence analysis according to six main activity statuses and subsequent cross tabulation showed that early leavers did not end up unemployed more commonly than ultimately displaced workers, and the predominance of the unemployment pension among the ultimately displaced workers was compensated for by the predominance of retirement among the early leavers. This demonstrates the role of institutions in buffering employment risks.

\section{The time to leave is not decisive for future earnings among the continuously employed}

In order to describe the development of the incomes in an unbiased setting - that is, in order to exclude the complex of social transfers - the analysis was focused on the earnings from work of those who assumed the trajectory of continuously strong labor market attachment. The result indicates that once an employee is re-employed without delay, the time that the employee left the employer is not decisive for future earnings. Nevertheless, rather than questioning the conclusions of previous studies (Farber 2005; Korkeamäki \& Kyyrä 2014; Schwerdt 2011), this result suggests that corresponding comparisons of income development should also be made in the groups that assume suboptimal labor market attachment.

\section{Strengths and limitations}

Our findings highlight the importance of the 'displaced worker bias' (Pfann \& Hamermesh 2008), since plants that carried out major downsizings in 2004 were excluded from the sample. Nevertheless, the time slot of one calendar year (2005) is rather wide and defining all those leaving at this time as 'ultimately displaced workers' is somewhat inexact. We wish to emphasize that the concept does not refer to downsizing or closure on a single date, but to a process that may consist of several dramatic arrangements over the target year. Therefore, we must bear in mind that for some of those who left in 2005, the nature of their departure was in fact 'early', rather than 'downsizing'. Despite this spillover, the study revealed significant differences in labor market 
attachment between the downsizing and early leavers. On the part of the early leavers, we must consider that there were employees who did not leave - or were not laid off - in relation to the upcoming downsizing but left due to ordinary staff turnover practices. Unfortunately, the available register data did not enable us to control such a 'turnover bias' empirically; however, we can assume that there were corresponding leavers also in 2005, and, therefore, the comparison in our study may be considered to be turnover-adjusted.

From the viewpoint of the plant and labor market adaptation, a major downsizing is a different process than a complete closure. However, from the viewpoint of the employees who leave, it is of relatively minor importance whether the former plant still exists or not. In addition, we can argue that both employee samples were uniform as regards their labor market position at the beginning of the follow-up. Moreover, we controlled the differences in the socioeconomic factors and earlier labor market attachment. One speculative explanation for the risk of poor employment among the early leavers is provided by the theories of human capital and occupation-specific labor market (Ormiston 2014). Although the level of human capital is largely determined by the workers' level of education - which was controlled in our analysis - it is possible that due to their particular occupations and work history, the human capital possessed by the ultimately displaced workers promoted their employability and job mobility. On the other hand, and as a specification to the general human capital argument, early leavers can be employed in other jobs; this includes the risk of a qualification mismatch, in particular, among the well-qualified employees who seem to suffer from over qualification, at least during the first years of re-employment (Nedelkoska et al. 2015) or those who have an outdated education.

The analysis could have been further refined by considering the impact of business cycles and specifying the wage and revenue analysis. Although a cyclical and time effect is crucial, we have not included those here, as they were analyzed in our previous studies (Jolkkonen et al. 2017a, 2017b).

One of the strengths of this research is the data. The integrated employer-employee database (FLEED) is managed by Statistics Finland, and the information is undoubtedly valid and comprehensive. The data also enabled the use of advanced statistics that elucidate the development of labor market attachment in more detail than the methods used in earlier studies. Moreover, the long follow-up, ranging from three years before the job loss up to seven years after the job loss, ensured that the different labor market attachment patterns were not due to temporary status transitions. As far as follow-up designs are considered, we can recommend checking the data with respect to applying trajectory or sequence analyses; these methods are currently available in several statistics packages and await more widespread utilization in the social sciences.

It is likely that potential differences in the public legal protection between the early leavers and the ultimately displaced workers were not crucially important, as the source of the employment periods in the FLEED database is the nation-level administrative register of the Finnish Centre for Pensions, which means that all the periods fulfilled the nation-level legal regulations. The data either contains information on the type of the employment relationship, such as temporary contract, or compensation for the termination of employment, which limits the assessment of the risks of job loss.

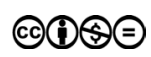


Finally, in a register study, it is not possible to consider employees' subjective perceptions, for instance, concerning the voluntariness of leaving. As such, there is a need for a 'displaced worker survey' (see Farber 2005) in Finland.

\section{Conclusions}

The results of this article seem to contradict previous research that argues that 'early leavers' are fortunate in terms of re-employment. According to our findings, the early leavers turn out to be a heterogeneous group: there are the lucky ones who move immediately on to the next job, probably taking advantage of their skills and strong labor market position, but there is also a relatively large group that settles on insecure employment and makes use of the options provided by welfare institutions. However, rather than dispute the evidence of those studies, which is based on data from the 1980s (survey data from the US and register data from Austria), it is important to conclude that the results of an early leaver study depend on the setting. We suggest that the difference is due to the differences and the changes that have taken place in the societal institutions and the functioning of the labor market during the decades that have passed since the data collection of earlier studies. Our 'deviant' finding was already suggested in an earlier study (Korkeamäki \& Kyyrä 2014) based on Finnish data from the 1990s, and in addition to confirming that finding with a stricter design in more recent labor markets, our study provides novel and detailed knowledge about post-separation restructuring and segmentation in the labor market. The polarization of outcomes was also indicated in our earlier case-study (Jolkkonen \& Kurvinen 2009).

With respect to economic development, the baseline years (2004 for the early leavers and 2005 for the ultimately displaced workers) represent a period of stable macroeconomic growth. Moreover, there were no major institutional changes between these years, such as industrial relations legislation, the Act on Co-operation within Undertakings (2007), or pension schemes. Partly, the early leavers' poorer re-employment may be explained by the 'last in, first out' principle (Kuhn 2002), although inclusion in the sample was conditional on being contracted for at least one year. Despite the analysis of a natural experiment in Sweden (von Below \& Skogman Thoursie, 2010) indicating that the effect of the seniority rule on net employment is rather small, it is possible that in distressed firms, the rule affects early leaving differently than downsizing leaving, especially when the downsizing leaving occurs through a plant closure. Unlike in several other countries, the seniority rule is not institutionalized in Finland by law or collective agreements, but it is a matter of labor market practice (von Bellow \& Skogman Thoursie 2010). As far as early leavers were selected by the employer, the rule means that the layoffs tended to hit those with a less established position in the organization and labor market. Also, our results are in line, although do not give direct empirical evidence, to the fact that the relative share of temporary employment is higher in Finland than, for example, in the other Nordic countries, and temporary employment is used as a means of labor flexibility (TEM raportteja 2012, p. 9).

All in all, we found a large group of 'lucky leavers' who seemed to move from one job to another, probably taking advantage of their skills and strong labor market position. However, there was also a considerable group consisting of those who settled in an insecure employment situation and made use of the options provided by welfare 
institutions. In pointing to the higher heterogeneity among the early leavers as regards segregation into the employment trajectories and utilization of the social security benefits of the welfare state, our results bring clear added value to the body of research on restructuring.

Arguing against the common belief that early leavers are winners in mass layoffs, we emphasize two points. In the short term, early leavers may find a new job immediately, and will, eventually, be trapped in unstable or low-paid jobs. However, it is important to bear in mind that the group of early leavers is internally polarized. This should be considered in both employment policies and in the targeting of support measures. To attain the high mobility and social sustainability in the labor market, policy makers should focus more on measures that make employment more sustainable in terms of stability, career development, and risk avoidance.

Considering the labor market attachment of the ultimately displaced workers as the gold standard, there seems to be space to increase strong attachment and to decrease weak attachment among the early leavers through particular policy measures. The measures should also be targeted according to the internal divisions between the early and ultimately displaced workers. The employees at risk should receive increased and improved information about the situation in the workplace and the options in the labor market. In addition to such 'early prevention', timely 'secondary preventive measures' are needed among those whose fears come true. The results make it clear that the measures should not only consist of arranging opportunities for re-education and rehabilitation, but also guiding such individuals through the jungle of the social insurance system. A model for such measures could be adopted from the best practices of the "change security' programs applied to actualized downsizing and closure crises (e.g., Jolkkonen $\&$ Kurvinen 2009). The major challenge in primary prevention is to make employers and employees recognize more sensitively and more accurately that they are in the state of anticipation, whereas secondary prevention requires resources and the innovative development of active labor market policy measures. Overall, in order to manage the restructuring of industries in a way that minimizes the risk of low qualified early leavers ending up on the margins of the labor market, employment policies and collective agreements evidently need to be revised in the direction of flexicurity (Muffels et al. 2014).

\section{References}

Abbott, A. (1995). Sequence analysis: new methods for old ideas, Annual Review of Sociology 21: 93-113. doi: https://doi.org/10.1146/annurev.so.21.080195.000521.

Addison, J. and Portugal P. (1987). The effect of advance notification of plant closings on unemployment, Industrial and Labor Relations Review 41(1): 3-16. doi: https://doi. org/10.1177/001979398704100101.

Aisenbrey, S. and Fasang, A. (2010). New life for old ideas: 'The second wave' of sequence analysis. Bringing the 'course' back into the life course, Sociological Methods \& Research 38 (3): 420-462. doi: https://doi.org/10.1177/0049124109357532.

Appelqvist, J. (2007). Wage and earnings losses of displaced workers in Finland, Discussion Papers No. 422, Government Institute for Economic Research, Helsinki, Finland.

Beam, E. (2016). Do job fairs matter? Experimental evidence on the impact of job-fair attendance, Journal of Development Economics 120(C):32-40. doi: https://doi.org/10.1016/j. jideveco.2015.11.004. 
von Below, D. \& Skogman Thoursie, P. (2010). Last in, first out? Estimating the effect of seniority rules in Sweden, Labour Economics 17(6) 987-999. doi: https://doi.org/10.1016/j. labeco.2010.02.007.

Böheim, R., Hovarth, G. and Winter-Ebmer, R. (2011). Great expectations: past wages and unemployment durations, Labour Economics 18 (6): 778-785. doi: https://doi.org/10.1016/ j.labeco.2011.06.009.

Bonin, H., Dohmen, T., Falk, A., Huffman, D. and Sunde, U. (2007). Cross-sectional earnings risk and occupational sorting: the role of risk attitudes, Labour Economics 14 (6): 926-937. doi: https://doi.org/10.1016/j.labeco.2007.06.007.

Bowlus, A. \& Vilhuber, L. (2001). Displaced workers, early leavers, and re-employment wages, CIBC Working Papers, 2001-5, CIBC Centre for Human Capital and Productivity, London, ON: Department of Economics, University of Western Ontario.

Bratsberg, B., Fevang, E. \& Røed, K. (2013). Job loss and disability insurance, Labour Economics 24 (C):137-150. doi: https://doi.org/10.1016/j.labeco.2013.08.004.

Brzinsky-Fay, C., Kohler, U. \& Luniak, M. (2006). Sequence analysis with Stata, The Stata Journal 6(4): 435-460. doi: https://doi.org/10.1177/1536867X0600600401.

Burda, M. \& Mertens, A. (2001). Estimating wage losses of displaced workers in Germany, Labour Economics 8 (1):15-41. doi: https://doi.org/10.1016/S0927-5371(00)00022-1.

Cahuc, P., Carcillo, S. \& Zylberberg, A. (2014). Labor Economics, MIT Press, Cambridge, US.

Eliason, M. \& Storrie, D. (2006). Lasting or latent scars? Swedish evidence on the long-term effects of job displacement, Journal of Labor Economics 24(4): 831-856. doi: https://doi. org/10.1086/506487.

Emmenegger, P., Häusermann, S., Palier, B. \& Martin S-K. (eds) (2012). The Age of Dualization: The Changing Face of Inequality in Deindustrializing Societies, New York, Oxford University Press.

Farber, H. (2005). What do we know about Job Loss in the United States? Evidence from the Displaced Workers Survey, 1984-2004, Working paper 498, Princeton University, Industrial Relations Section.

Folbre, N., Leighton, J. \& Roderick, M. (1984). Plant closings and their regulation in Maine, 1971-1982, Industrial and Labor Relations Review 37(2): 185-196. doi: https://doi. org/10.1177/001979398403700202.

Frederiksen, A. \& Westergaard-Nielsen, N. (2007). Where did they go? Modelling transitions out of jobs, Labour Economics 14(5): 811-828. doi: https://doi.org/10.1016/j.labec0.2006.09.003.

Gauthier, J-A., Widmer, E., Bucher, P. \& Notredame, C. (2010). Multichannel sequence analysis applied to social science data, Sociological Methodology 40(1):1-38. doi: https://doi. org/10.1111/j.1467-9531.2010.01227.x.

von Greiff, J. (2009). Displacement and self-employment entry, Labour Economics 16(5): 556-56. doi: https://doi.org/10.1016/j.labeco.2009.02.005.

Henningsen, M. \& Hægeland, T. (2008). Downsizing as a sorting device. Are low-productive workers more likely to leave downsizing firms? Discussion Papers No. 543, Statistics Norway.

Holmlund, B. \& Lang, H. (1985). Quit behaviour under imperfect information: searching, moving, learning, Economic Inquiry 23(4): 382-393. doi: https://doi.org/10.1111/j. 1465-7295.1985.tb01774.x.

van Huizen, T. \& Alessie, R. (2016). Risk aversion and job mobility, Discussion Paper Series/ Tjalling C. Koopmans Research Institute 16.09.

Huttunen, K., Møen, J. \& Salvanes, K. (2011). How destructive is creative destruction? Effects of job loss on job mobility, withdrawal and income, Journal of the European Economic Association 9(5): 840-870. doi: https://doi.org/10.1111/j.1542-4774.2011.01027.x. 
Jolkkonen A. \& Kurvinen, A. (2009.: Joustavuus ja turvallisuus irtisanomistilanteessa Tapaustutkimus Perlos Oyj:n tuotannon lopettamisesta Joensuun seudulla. [Flexibility and security in a lay-off situation - A case study of the closing down of the Perlos Ltd plants in the Joensuu region], Työ- ja elinkeinoministeriön julkaisuja. Työ ja yrittäjyys 72/2009.

Jolkkonen, A. Koistinen, P. Kurvinen, A. Lipiäinen, L. Nummi, T. \& Virtanen, P. (2017a) Labour Market Attachment Following Major Workforce Downsizings: A Comparison of Displaced and Retained Workers, Work, Employment \& Society 32(6): 992-1010. doi: https://doi.org/10.1177/0950017017706305

Jolkkonen, A. Koistinen, P. Kurvinen, A. Lipiäinen, L. Nummi, T. \& Virtanen, P. (2017b). Time of displacement as a predictor of re-employment, Nordic Journal of Working Life Studies 7(2): 87-106. doi: https://doi.org/10.18291/njwls.v7i2.81596.

Jung, T. \& Wickrama, K. (2008). An introduction to latent class growth analysis and growth mixture modeling, Social and Personality Psychology Compass 2(1): 302-317. doi: https://doi.org/10.1111/j.1751-9004.2007.00054.x

Knabe, A. \& Rätzel, S. (2011). Scarring or scaring? The psychological impact of past unemployment and future unemployment risk, Economica 78(310): 283-293. doi: http:// dx.doi.org/10.1111/j.1468-0335.2009.00816.x

Korkeamäki, O. \& Kyyrä, T. (2014). A distributional analysis of earnings losses of displaced workers in an economic depression and recovery, Oxford Bulletin of Economics and Statistics 76, pp. 565-588.

Lengermann, P. \& Vilhuber, L. (2002). Abandoning the sinking ship: the composition of worker flows prior to displacement, Technical Paper TP-2002-11. U.S. Census Bureau, LEHD Program.

Lindbeck, A.\& Snower, D.J. (1991) Interactions between the efficiency wage and insideroutsider theories. Elsevier. Economics Letters 37(2): 193-196. doi: https://doi.org/ 10.1016/0165-1765(91)90130-D.

Lim, V., Chen, D., Aw, C. \& Tan, M. (2016). Unemployed and exhausted? Job-search fatigue and reemployment quality, Journal of Vocational Behavior 92: 68-78. doi: https://doi. org/10.1016/j.jvb.2015.11.003.

Lindbeck, A. \& Snower D.J. (2001) Insiders versus outsiders, Journal of Economic Perspectives 15(1): 165-188. doi: https://www.jstor.org/stable/2696546? seq=1.

Martikainen, P., Mäki, N \& Jäntti, M., (2007) The effects of unemployment on mortality following workplace downsizing and workplace closure: a register-based followup study of Finnish men and women during economic boom and recession, American Journal of Epidemiology 165(9): 1070-1075. doi: https://doi.org/10.1093/aje/kwm057.

McCall, J. (1970). Economics of information and job search, Quarterly Journal of Economics 84(1): 113-126. doi: https://doi.org/10.2307/1879403.

Mortensen, D. (1970). Job search, the duration of unemployment, and the Phillips curve, American Economic Review 60(5): 505-517. doi: https://www.jstor.org/stable/1818285

Muffels, R., Crouch, C. \& Wilthagen, T. (2014). Flexibility and security: national social models in transitional labour markets, Transfer: European Review of Labour and Research 20(1):99-114. doi: https://doi.org/10.1177/1024258913514361.

Muthén, B. (2001). Latent variable mixture modeling, Marcoulides G. \& Schumacker, R., New Developments and Techniques in Structural Equation Modeling, Erlbaum Associates, Lawrence, 1-33.

Muthén, B. (2004). Latent variable analysis: Growth mixture modeling and related techniques for longitudinal data, Kaplan, D., Handbook of quantitative methodology for the social sciences, Sage Publications, Newbury Park, CA, 345-368.

Nagin, D. (1999). Analyzing developmental trajectories: Semi-parametric, group-based approach, Psychological Methods 4(2):39-177. doi: https://doi.org/10.1037/1082-989X. 4.2.139. 
Nagin, D. (2005). Group-based modeling of development, Cambridge, MA: Harvard University Press.

Nedelkoska, L., Neffke, F. \& Wiederhold, S. (2015). Skill Mismatch and the Costs of Job Displacement. Center for International Development at Harvard University (CID) Research Fellow and Graduate Student Working Paper No. 122, September 2015.

Ormiston, R. (2014). Worker displacement and occupation-specific human capital, Work and Occupations 41(3): 350-384. doi: https://doi.org/10.1177/0730888414531500.

Pfann, G. \& Hamermesh, D. (2008). Two-sided learning, labor turnover and worker displacement, Jahrbücher für Nationalökonomie und Statistik 228(5): 423-445.

Schwerdt, G. (2011). Labour turnover before plant closure: "Leaving the sinking ship" vs. "Captain throwing ballast overboard, Labour Economics 18(1): 93-101. doi: https://doi. org/10.1016/j.labeco.2010.08.003.

Stigler, G. (1961). The economics of information, Journal of Political Economy 69(3): 213-225. doi: https://doi.org/10.1086/258464.

Stigler, G. (1962). Information in the labor market, Journal of Political Economy 70(5): 94-105. doi: https://doi.org/10.1086/258727.

TEM Raportteja (2012) Työvoiman käyttötapojen ja työn tekemisen muotojen muutostrendejä selvittävän ja kehittävän työryhmän väliraportti [Interim report of the working group examining and developing change trends in the use of the labour force and in the ways of work], TEM Raportteja 16/2012, Työ- ja elinkeinoministeriö, Helsinki.

Valenduc, G. (2018) Technological revolutions and societal transitions, ETUI Research Paper - Foresight Brief, 04-April 2018.

Verho, J. (2008) Scars of recession: the long-term costs of the Finnish economic crisis, Working paper 9. IFAU - Institute for Labour Market Policy Evaluation, Uppsala.

\section{Note}

i After the last follow-up year 2005, the unemployment pension was abolished as pension type in connection with the Finnish 2005 Pension Reform 2005. The unemployment pension was replaced by the unemployment allowance, so-called additional days. (https://www. etk.fi/en/the-pension-system/dynamic-pension-scheme/pension-reform-in-2005/early-retirement-pensions/). 